\section{RIMCIS \\ Social Sciences}

\section{Hipatia Press}

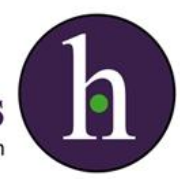

Instructions for authors, subscriptions and further details:

http://rimcis.hipatiapress.com

\title{
Contextualization-Emotionalization Interface: A Case of Teacher Effectiveness
}

Reza Pishghadam ${ }^{1}$, Shaghayegh Shayesteh ${ }^{1}$, Simindokht Rahmani ${ }^{1}$

1) Ferdowsi University of Mashhad, Iran

Date of publication: July $30^{\text {th }}, 2016$

Edition period: July 2016 - November 2016

To cite this article: Pishghadam, R., Shayesteh, S., \& Rahmani, S. (2016). Contextualization-Emotionalization Interface: A Case of Teacher Effectiveness. International and Multidisciplinary Journal of Social Sciences, 5(2), 97-127. doi: 10.17583/rimcis.2016.1907

To link this article: http://doi.org/10.17583/rimcis.2016.1907

\section{PLEASE SCROLL DOWN FOR ARTICLE}

The terms and conditions of use are related to the Open Journal System and to Creative Commons Attribution License (CC-BY). 


\section{Contextualization- Emotionalization Interface: A Case of Teacher Effectiveness}

Reza Pishghadam

Ferdowsi University of Mashhad

Simindokht Rahmani

Ferdowsi University of Mashhad
Shaghayegh Shayesteh

Ferdowsi University of Mashhad

\section{Abstract}

Given the prominence of cognitive and affective factors in teacher effectiveness, this study intends to look at the issue from a different perspective and examine the roles of contextualization and emotionalization in teacher success. In so doing, 305 English as a Foreign Language (EFL) learners rated their English teachers to determine the extent to which they contextualize and emotionalize their instructions. During the first phase of the study, a pair of scales were constructed and substantiated via Confirmatory Factor Analysis (CFA) to serve the abovementioned purpose. As for the second phase, Structural Equation Modeling (SEM) was utilized to shed light on any probable relationships among the independent variables and teacher success. The results indicated that, teachers who contextualize and emotionalize their instructional practices, enjoy an enhanced level of success. Moreover, it was revealed that, in the close competition between contextualization and emotionalization, contextualization was identified as a slightly better predictor of teacher success. Building upon the rather strong links between the sub-construct of contextualization and emotionalization, it was further inferred that, mutual juxtaposition of the two concepts contribute to teacher success. In the end, the results were discussed in the realm of English language education.

Keywords: emotion, cognition, emotionalization, contextualization, effective teaching 


\section{La Interrelación Contextualización- Emocionalización: Un Caso de Efectividad Educativa}

Reza Pishghadam

Ferdowsi University of Mashhad

Simindokht Rahmani

Ferdowsi University of Mashhad
Shaghayegh Shayesteh

Ferdowsi University of Mashhad

\section{Resumen}

Dada la prominencia de los factores cognitivos y afectivos en la efectividad educativa, este estudio intenta abordar el tema desde una perspectiva diferente y examina los roles de la contextualización y de la emocionalización en el éxito educativo. Al hacerlo, 305 estudiantes de Inglés como Lengua Extranjera (ILE) calificaron a sus profesores de Inglés para determinar hasta qué punto contextualizaban y emocionalizaban sus instrucciones. Durante la primera fase del estudio se construyeron y sustanciaron un par de escalas a partir de Análisis Factorial Confirmatorio (AFC). Mientras que durante la segunda fase se utilizó la Modelización de Ecuaciones Estructurales (MEE) para esclarecer cualquier probable relación entre las variables independientes y el éxito educativo. Los resultados indicaron que el profesorado que contextualiza y emocionaliza sus prácticas instructivas disfruta de un mayor éxito. Aún más, se descubrió que en la competición entre contextualización y emocionalización, la primera apareció como un predictor ligeramente mejor del éxito educativo. Construido sobre los suficientemente fuertes vínculos entre el sub-constructo contextualización y emocionalización, se llegó a inferir que la yuxtaposición de ambos conceptos contribuye al éxito educativo. Al fin y al cabo, los resultados se discutieron en el ámbito del aprendizaje de la lengua inglesa.

Palabras clave: emoción, cognición, emocionalización, contextualización, efectividad educativa 


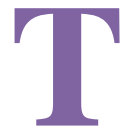

he integrity of every educational system depends largely upon the performance of its teachers. Although they are merely one serve numerous roles and take different responsibilities in the classroom. During recent decades, they have attracted burgeoning attention to the extent that their success, or so called effectiveness, has turned into the "focus of educational policy in the $21^{\text {st }}$ century" (Mangiante, 2011, p. 42).

Almost all the decisions made about teachers originate from their quality of success. Yet, there exists a lack of general consensus regarding which characteristics of teachers contribute to their overall success (Palardy \& Rumberger, 2008). The literature has widely investigated attributes associated with teacher success, varying from teachers' personal and professional qualities (e.g., Bhardwaj, 2009; Elizabeth, May \& Chee, 2007; Medley \& Mitzel, 1955; Porter \& Brophy, 1988) to working conditions and environment (Johnson \& Birkeland, 2003; Korthagen, 2004). Be that as it may, in light of the conducted studies, evaluation of teacher success focusing exclusively on teachers' capabilities to handle subject-related and didactical issues seems inadequately narrow. A noteworthy consideration is that, teachers, though implicit in nature, take on much vaster roles with regards to their students' lives which may likewise influence their professional success to various degrees. In this vein, from amongst teachers teaching many different subjects, English language teachers, relying on the unique nature of their classes, adopt a life-changing role and, more than their counterparts, endeavor to shape students' idiosyncratic lives (Pishghadam \& Zabihi, 2012).

In reality, students come to school with a prearranged bundle of experiences, wondering about the relevance of what they study. These experiences might be of great use contributing to both cognitive and affective domains of learning. If effectively employed, learners are able to draw upon their prior experiences so as to learn the new materials (Son \& Goldstone, 2009). A typical cognitive application of linking these real world practices to English language classroom instructions is central to contextualization (Walz, 1989). Traditionally, this challenging responsibility was left to students themselves. However recently, numerous scholars (e.g., Celce-Murcia, 2002; Thornbury, 1999) have reported improved 
achievements on the part of learners once they are assisted to make connections between academic learning and their prior real world experiences. Given the popularity of contextualization and the bulk of studies conducted on it (e.g., Cordova \& Lepper, 1996; Shrum \& Glisan, 1994), not much has been said on the relationship between one such key concept and teacher success in English language teaching (ELT), in part because it was perhaps more difficult to measure or quantify.

In addition to the cognitive aspect of learning through experiences, the merits of contextualization might be otherwise explicated through the affective notion of emotionalization. In 2013, Pishghadam, Tabatabaeyam, and Navari, moved a step beyond pure contextualization and magnified the emotional context rather than the social or lexical context, arguing that emotion is one of the main forces behind language learning and teaching. Thus, it is actually believed that, being mindful of students' real world experiences might be a further leap toward educational improvement and ultimately teacher success.

On the whole, our immediate point of departure is to cast more light on the exclusive nature of ELT classes and reorient the definition of teacher success from contextualization and emotionalization standpoints. Since the two concepts do not amount to the same thing (cognition vs. emotion), it is particularly aimed to compare and contrast their strength in predicting teachers success. To make the case, a pair of scales are constructed and validated to measure the extent to which English teachers contextualize and emotionalize their instructions in ELT classrooms.

\section{Theoretical Framework}

\section{Teacher Success}

Teacher success is a complex construct and there is a scant agreement concerning the way it should be defined. Its definitions fluctuate from experience and credentials to behavior and instructional strategies. In general, a successful teacher is conceptualized as the one whose ultimate attempts lead to his/her learners' enhanced academic achievement (Uchefuna, 2001). 
The research to uncover the attributes of successful teachers has such a long history. Professional debate and interest in identifying superior and inferior teachers developed since the early 1920s and experienced its heyday in the 1980s and early 1990s. During the course of time, the features of teacher effectiveness have undergone many changes as different teaching methodologies and approaches and their underlying psychological assumption shaped up (Ellett \& Teddlie, 2003). For instance, behaviorism evaluated teacher effectiveness according to achievement and product, while cognitivism steered the focus on the process of learning and teaching. Later, during the reform movement, implications for teachers' effectiveness included various effective, cognitive, and social characteristics (Monshi Toussi, Boori \& Chanizadeh, 2011).

In consequence, being a successful teacher has come to encompass many dimensions during the last few decades, leading many researchers to labor to identify the common characteristics. A number of studies have highlighted the role of teachers' level of education, intelligence, personality, and years of experience (e.g., Bhardwaj, 2009; Dodge, 1943), whereas others have put their fingers on the instructional objectives and classroom practices rather than the teachers' individual background characteristics (e.g., Brophy, 1988; Campbell, Kyriakides, Muijs \& Robinson, 2004). Quite differently, some have also given prominence to the environment and working conditions including factors such as school facilities, administrators, and teaching materials (Johnson \& Birkeland, 2003; Korthagen, 2004).

Indeed there is no one particular way to become an effective teacher (Monshi Toussi et al., 2011). In recent years, the literature on teacher success has chiefly revolved around the instructional strategies teachers employ and the ways they treat the learners, concluding that the most widely studied features often give more weight to psychological and instructional factors. For instance, from a psychological standpoint, Dodge (1943) depicts successful teachers as more sociable, sensitive to people's opinions, responsible, and less worried. Along similar lines, Beck (1967) argues that, successful teachers are perceived as warm, supportive, and friendly by students. In another attempt, the ability and skill of teachers using neurolinguistic programming (NLP) techniques is concluded to correspond directly with teacher flexibility; hence with teacher success (Pishghadam, 
Shayesteh \& Shapoori, 2011). Furthermore, from the instructional stand point, Porter and Brophy (1988) believe that, successful teachers have the ability and skill to plan, employ materials, assess, and evaluate. According to Campbell et al. (2004), effective teachers have organizational and classroom management abilities, provide learners with adequate quantity of instruction and practice, and are well-read and knowledgeable.

By and large, although literature paints a nice picture of the aspects influencing teacher success, the conventional conception of teacher success is no longer able to fulfill the needs of the dynamic educational systems. Given its continuing significance, the concept needs to be frequently revisited and revised. In this regard, an undeniable role of teachers which has remained overlooked so far is relevant to their learners' experiences outside the classroom. Teachers need to make a bridge between the two worlds in such a way to live up to their learners' prior expectations and reinforce their own success. Thus, contextualization may be a helpful cognitive joint to invest in.

\section{Contextualization}

A prevalent theoretical view underlying numerous recent improvements in education, acknowledge the learners as the principal agents of every class. In line with this movement, literature has witnessed a switch of focus away from the static, monolithic concept of 'context' towards the dynamic notion of 'contextualization' which gives further prominence to the salience of learner engagement (Baker, 2006). Aiming toward providing better conditions for effective, meaningful learning (Son \& Goldstone, 2009), contextualization attracted considerable attention as one of the most extensively invoked processes of language teaching (Bax, 2003). This typical trend is defined in a number of rather distinct ways. According to the most common one, language contextualization is simply delineated as putting language in a meaningful and real context (Walz, 1989), which stands in contrast to de-contextualized practices where language items are treated in isolation.

An array of studies compiled throughout its history, directs us to two different forms of contextualizing language instruction both of which target 
at creating conditions for more purposeful learning: 1) the incorporation of background knowledge and context into language instruction, and 2) the connection of language instruction to application and life goals (Nunan, 1999), assuming that, the ultimate goal of learning a language is to be able to use it in a real life context (Richards \& Rodgers, 2001). The theoretical basis underpinning this form of instruction rests, for the most part, upon research in cognitive science including Ausubel's Subsumption Theory (1968), which sets what the learners already know as an indicator of what they subsequently will learn. A further theory that corroborates the application of contextualization in language teaching is Schema Theory (Bartlett, 1932), according to which language comprehension and recall is fostered by preexisting knowledge. It is indeed believed that, full comprehensibility grows out of a concrete set of real world experiences as opposed to the traditional practices in which learners would labor to associate with decontextualized abstract entities (Son \& Goldstone, 2009).

Establishment of connections between situations outside and inside the classroom is crucial for the learners to be able to transfer their knowledge and skill (Stone, Alfeld, Pearson, Lewis \& Jensen, 2006). From an empirical point of view, several researchers have come up with similar conclusions. Cameron (2001) accentuated the links existing between different activities and pointed out the thread of theme and topic running through everything that happens in and out of the classroom. Brown (2000) further contended that, meaningful learning, as opposed to rote learning, takes place when learners relate the new learning task to what they already know. To boot, Shrum and Glisan (1994) equally highlighted the importance of relating new information to previous knowledge for promoting comprehension.

In a nutshell, contextualized knowledge has been pointed out in the literature as constantly more valuable than decontextualized knowledge (e.g., Celce-Murcia, 2002). In the same vein, Pishghadam, Tabatabaeyan et al. (2013) take this further stating that the affective facet of contextualization, technically referred to as emotionalization, gets further past its conventional cognitive facet, for a dearth or absence of prior emotion could prove more hindering than inadequate or no prior knowledge. 


\section{Emotionalization}

The long-standing controversy between cognition and emotion dwells on whether "emotion is primary and independent of cognition, or secondary and always depend upon cognition" (Leventhal \& Scherer, 1987, p. 3). Emotion, as the critical missing piece within language education domain, is highlighted by Greenspan (1992) as the primary element in the development of the child's early functional and social improvement. Affect and supportive relationships are the foundations of his widely known Developmental Individual-Difference Relationship-Based model (DIR). Later in 2013, inspired by Greenspan's DIR model of first language (L1) acquisition, Pishghadam, Adamson et al. (2013) pioneered a new approach to second language (L2) acquisition called Emotion-Based Language Instruction (EBLI). Following the same missing piece underlined by Greenspan (1992), EBLI, gives emphasis to the significance of learners' emotional capacities, notably those they bring into play from their L1 experience.

EBLI explains itself through the introduction of three key concepts to the literature: Emotioncy, Emotionalization, and Inter-emotionality (Pishghadam, Adamson et al., 2013). According to Pishghadam, Adamson et al. (2013), every individual has a degree of emotion -referred to as emotioncy- towards different language entities. In other words, some words have higher emotioncy for certain individuals only because they have heard, seen, smelled, touched, or experienced them in one way or another. Such entities are learned faster and easier compared to those for which one may have lower or no emotioncy. The theoretical basis underlying this argument is a newly developed dimension of constructivism introduced by Pishghadam (2015). Sensory constructivism, as opposed to cognitive constructivism (Piaget, 1959) and social constructivism (Vygotsky, 1978), arises from taking advantage of one's senses to navigate and construct his/her own understanding of the world. In order to broaden the concept, Pishghadam (2015) put emotioncy on a continuum, assigning degrees to each type of emotioncy with 0 for no emotioncy, 1 for Auditory emotioncy, 2 for Visual emotioncy, 3 for Kinesthetic emotioncy, 4 for Inner emotioncy, and 5 for Arch emotioncy. To explicate, while Auditory emotioncy is 
experienced when an individual has merely heard a word/concept, Visual emotioncy is experienced when that item is both heard and seen. Kinesthetic emotioncy indicates the emotion one may have while touching, working, or playing with the real object. Inner emotioncy is developed when an individual directly experiences an entity. Arch emotioncy, as the ultimate type, is developed when emotion is strengthened by being deeply involved in an object/idea as a result of doing research or surfing the net to get additional information in that regard. As the illustration depicts (Figure 1), the term exvolvement initiates when Auditory emotioncy is developed. During this phase, learning has occurred through indirect involvement, yet has not been fully internalized. Moving toward the end of the continuum, involvement gradually evolves out of exvolvement, while being directly involved in learning a word/concept. Transcending from the Exvolvement to Involvement levels of emotioncy ends to a better understanding of reality. This is what Pishghadam, Jajarmi, and Shayesteh (in press) refer to as sensory relativism propounding that emotions, resulted from our sensory experiences, can relativize cognition.

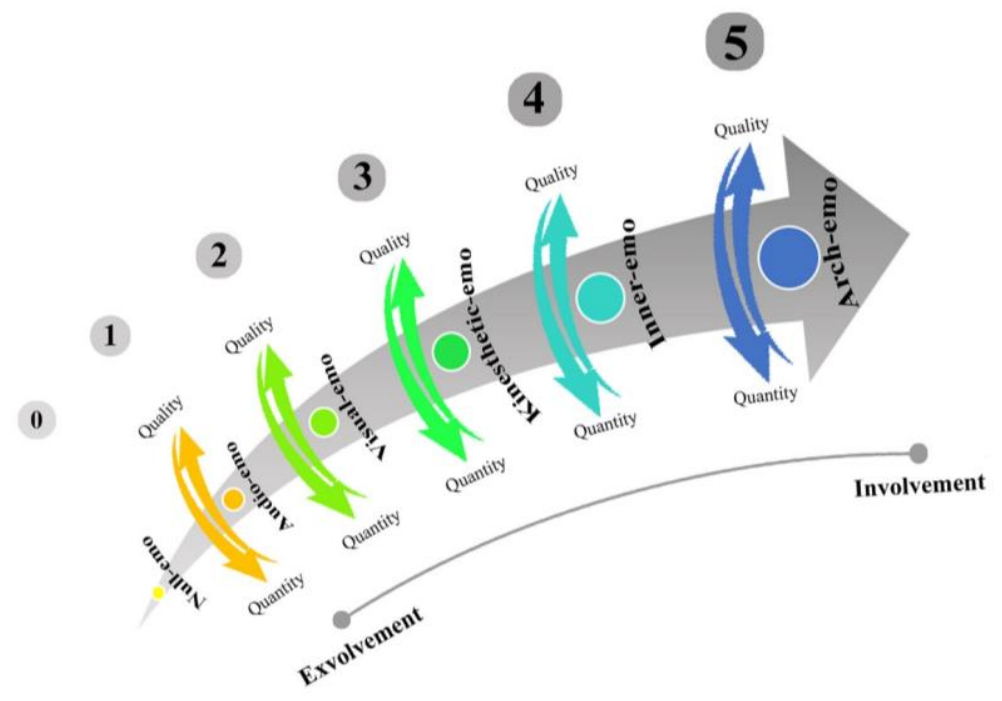

Figure 1. Emotioncy Levels

Source: Pishghadam, 2015 
With regards to the second term, emotionalization has been defined by Pishghadam, Adamson et al. (2013, p. 9) as "building emotions towards L2 lexical items". The idea behind drawing emotional links between L1 and L2 lexical items comes from Greenspan (2001), stating that it is the emotional context which gives meaning to words. Pishghadam, Adamson et al. (2013) draw upon this principle and continue to suggest that L2 instruction should tap into learners' already-possessed 'world' (pragmatic dimension of a language) and target at teaching the missing 'word' (semantic dimension of a language) only. As a result, learners may learn vocabulary items equivalent to their L1 better and faster, building upon their previous emotional knowledge. This flow of emotions moving between L1 and L2 is called inter-emotionality. The direction of this flow can either hinder or facilitate the process of second language acquisition (Pishghadam, Adamson et al., 2013).

In an empirical study, Emotioncy was employed as a determiner of word saliency (Pishghadam \& Shayesteh, in press), so as to challenge Widdowson (2004) and his idea of frequency, coverage, and prototype, as main features in estimating the salience of words. Three groups of learners were selected from three different socio-economic status (i.e., high, medium, and low). The final results indicated that, the degree of vocabulary learning declines as the learners move from high to low socio-economic class, believing that "access to social and cultural capital brings about emotioncy" (Pishghadam $\&$ Shayesteh, in press).

Given that "emotional engagement provides meaningfulness" (Pishghadam \& Shayesteh, in press), it may do a service for teachers too. The aforementioned literature reveals the importance of contextualization and emotionalization in language teaching and learning, and highlights teachers' abilities and skills as a facet of teacher success. In order to bring about a shift in the conception of teacher success, the present study attempts to draw a link between contextualization and emotionalization and investigate their relative importance in teacher success through constructing and validating scales for each of them. The logic behind investigating these two factors and their hypothesized relationship with teachers' level of success is that, the teachers who effectively consider the cognitive and affective experiences learners bring to the ELT classroom, are more likely to 
be successful than those who adhere to the conventional instructional routines. In particular the current study intends to address the following research questions:

1. Is there any significant relationship between contextualization and teacher success?

2. Is there any significant relationship between emotionalization and teacher success?

3. Which one has a more significant relationship with teacher success: emotionalization or contextualization?

\section{Methodology}

\section{Participants}

A total number of 305 EFL learners participated in the present study rating their 27 English teachers in regard to the extent to which they contextualize and emotionalize while teaching. The sample consisted of 179 female, 123 male, and 3 unknown language learners studying in 6 private language institutes in Mashhad, Iran with their age ranging from 15 to $62(\mathrm{M}=22.5)$. They were selected based on convenience sampling and from the six different proficiency levels of beginner, elementary, lower-intermediate, intermediate, upper-intermediate, and advanced. The levels were drawn from the common policy in institutes where learners are assigned to each level based on either the placement test for newcomers, or achievement tests held at the end of each term allowing students to taking part in the class appropriate to their proficiency level.

\section{Instruments}

\section{Characteristics of Successful EFL Teachers Questionnaire}

Characteristics of Successful EFL Teachers questionnaire, developed by Moafian and Pishghadam (2008), was employed to investigate teachers' success in the classroom. This is a 47-item Liker-type questionnaire varying 
from 1 (strongly agree) to 5 (strongly disagree). The results of factor analysis conducted by Moafian and Pishghadam (2008) has confirmed its construct validity with the scale measuring teaching accountability, interpersonal relationships, attention to all, examination, commitment, learning boosters, creating a sense of competence, teaching boosters, physical and emotional acceptance, empathy, class attendance, and dynamism. The overall reliability of the questionnaire, using Cronbach`s alpha was .94 and in the current study it is .89 .

\section{Contextualization Scale}

A second scale was developed by the authors according to the Nunan's (1999) twofold image of language contextualization to investigate the extent to which an English teacher tries to put the language into a meaningful and real context (Appendix 1). This scale consists of 10 items and construes contextualization as a two-dimensional concept each measured with 5 items: Life (e.g., my teacher makes us work on tasks which are directly related to our life goals) and Language (e.g., my teacher asks us to pay attention to the physical settings such as pictures, maps, objects, etc.). Cronbach's alpha calculated for the scale was .81. The sub-constructs have also demonstrated the reliability of .69 and .79 , respectively. The survey uses a 5-point Likert scale ranging from 1 (never/rarely) to 5 (always). Items 5 and 8 have been reverse-scored due to their negative wording.

\section{Emotionalization Scale}

Based on the metric of emotioncy levels introduced by Pishghadam (2015), the authors designed a 30-item scale (Appendix 2). Throughout the validation process, 7 items were deleted leaving the validated scale with 23 items covering the 5 types of emotioncy: 1. Auditory Emotioncy measured with 5 items, such as "my teacher does not change her tone of voice while talking about/ teaching certain concepts", 2. Visual Emotioncy tapped by 5 items, including "my teacher uses different facial expressions while talking about/ teaching certain concepts", 3. Kinesthetic Emotioncy measured with 4 items, including "my teacher wants us to act out/ mime some concepts", 4. 
Inner Emotioncy measured with 4 items, such as "my teacher invites native/ native like speakers to the class", and finally 5. Arch Emotioncy tapped by 4 items, including "my teacher wants us to compare and contrast certain concepts through further readings and discussion". The items rate 1 (never/rarely) to 5 (always) on a Likert scale assessing the extent to which an English teacher tries to emotionalize the language and help students connect emotionally with different pedagogical concepts (Pishghadam, Adamson et al., 2013). Negatively worded items of the scale (i.e., 3, 9, 14, 21, and 27) were reverse- scored prior to data analysis. Using Cronbach's alpha, the results of reliability analysis has yielded the overall reliability of .82 ranging from .77 to .81 for each single sub-construct.

\section{Procedure}

Prior to data collection, the two scales of contextualization and emotionalization were developed based on the literature related to each concept. First, the authors prepared at least 6 items for each emotioncy level (see Figure 1) in emotionalization scale and a minimum of 6 items for each aspect of contextualization scale. Next, they discussed the items and decided on 5 items for each level of emotioncy as well as each aspect of contextualization. Two experts in the fields of language teaching and educational psychology approved the content validity of the scales. Finally, both scales were piloted with 15 students. Based on the students' feedback on the content and language of the scales, some items were paraphrased and modified in both scales to ensure their comprehensibility.

The data collection was conducted during the end of the term in different language institutes in Mashhad, a city in Iran. The three scales were given to the students asking them to rate their current term teachers. Before the administration stage, permission was obtained both from the management in each language institute and teachers. Moreover, students were assured of the confidentiality of their responses and reminded that participation was voluntary. The authors decided to administer all the scales in the students' mother tongue (Persian), for students from varying levels of proficiency were taking part in the study. One of the authors was present while the students were filling in the scales so as to help them in case they had 
questions; this was especially due to the newness of the concept of emotionalization and students' unfamiliarity with the practices of its kind. Overall, it took about 20 minutes for the participants to complete the scales. To measure the reliability of the scales via Chronbach's alpha, SPSS (Version 20) was used. Next, to substantiate the construct validity of the scales and confirm the latent factors underlying each scale, Confirmatory Factor Analysis (CFA) was employed using Amos (Version 18). CFA is generally used to investigate the extent to which the variables are consistent with the number of constructs (Fox, 2010). Finally, the relationships among the latent variables were analyzed through Structural Equation Modeling (SEM). The application of SEM in the current study can be justified from two different aspects. First, the analytic solidarity of SEM, which is in fact rooted in its ability to process simultaneous equations encompassing a number of dependent and independent variables, exceeds that of other statistical techniques such as regression analysis. The second logic is that SEM includes latent variables which can be prevalent in testing the hypotheses whose constructs cannot be analyzed directly. Inclusion of latent variables, in the realm of social sciences, makes the prediction models more realistic seeing that researchers are always dealing with human beings whose performance is affected by various factors such as error factors, and cannot be measured precisely (Pishghadam \& Shams, 2012).

\section{Results}

\section{Descriptive Statistics and Correlations}

This study was conducted to construct and validate two scales to measure contextualization and emotionalization and find out their relationship with teacher success. Table 1 demonstrates the descriptive results along with the Pearson Product-Moment Correlation estimates between teacher success and contextualization and emotionalization, respectively. 
Table 1

Descriptive Statistics and Correlations

\begin{tabular}{|c|c|c|c|c|c|c|c|c|c|c|c|c|}
\hline & Mean & SD & & & & & & & & & & \\
\hline Arch & 1.41 & .15 & & & & & & & & & & \\
\hline Inner & 1.12 & .12 & & & & & & & & & & \\
\hline Kinesthetic & 3.32 & .54 & & & & & & & & & & \\
\hline Visual & 3.31 & .28 & & & & & & & & & & \\
\hline Auditory & 2.98 & .44 & & & & & & & & & & \\
\hline Life & 3.50 & .23 & & & & & & & & & & \\
\hline Language & 3.12 & .18 & & & & & & & & & & \\
\hline Contextualization & 3.45 & .88 & & & & & & & & & & \\
\hline Emotionalization & 3.34 & .98 & & & & & & & & & & \\
\hline Teacher Success & 3.18 & .70 & $.30^{*}$ & $.29 \%$ & $.51^{* *}$ & $.48^{* * *}$ & $.37 * *$ & $.54 * *$ & $.46^{* * *}$ & $.61^{* *}$ & $.58 * *$ & 1.00 \\
\hline
\end{tabular}

$* \mathrm{p}<.05 \quad * * \mathrm{p}<.01$

As can be seen in Table 1, there are significant positive relationships between teacher success and contextualization $(r=.61, \mathrm{p}<.01)$ and teacher success and emotionalization $(\mathrm{r}=.58, \mathrm{p}<.01)$ implying that, teachers who contextualize and emotionalize more, are likely to be more successful. A deeper analysis reveals that, the correlation between teacher success and contextualization is to some extent higher than the correlation between teacher success and emotionalization. That is to say, the significance of emotion is relatively comparable to that of cognition.

Moreover, Table 1 exhibits significant and positive correlations between teacher success and sub-constructs of contextualization $(r=.54$ for Life, and $\mathrm{r}=.46$ for Language) and sub-constructs of emotionalization (ranging from .29 for Inner to .51 for Kinesthetic). Among the sub-constructs of both scales, Inner emotioncy from emotionalization scale $(r=.29, \mathrm{p}<.05)$ and Life from contextualization scale $(r=.54, \mathrm{p}<.01)$ had the lowest and highest correlation with teacher success, respectively. 
112 Pishghadam et al. - Contextualization-Emotionalization Interface

\section{Inferential Statistics}

\section{Confirmatory Factor Analysis}

In order to substantiate the construct validity of the scales CFA was used.

\section{Contextualization Scale}

The results of the first CFA specified a model of contextualization scale with 2 continuous latent variables, Life and Language, and 5 observed dependent variables for each factor (Figure 2).

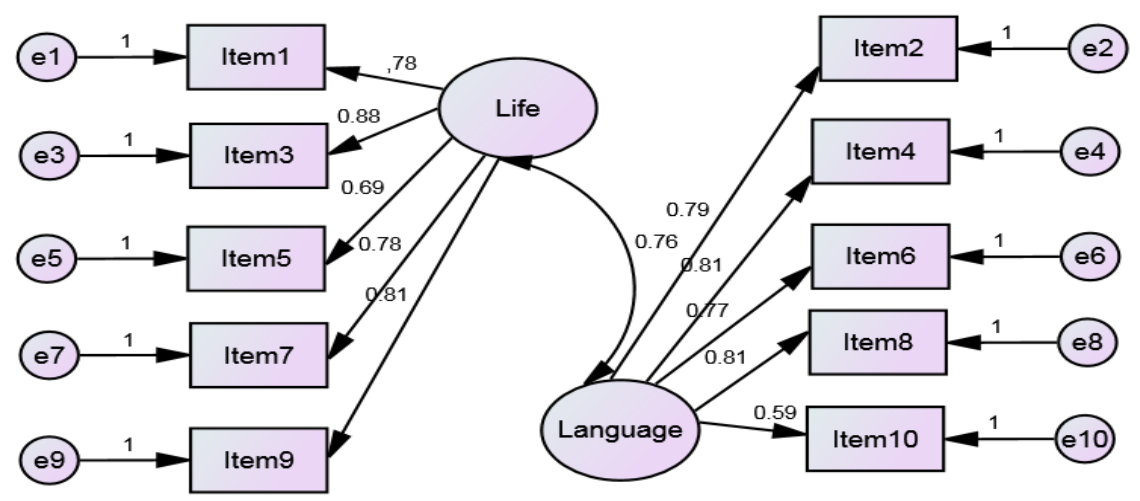

Figure 2. CFA Model for Contextualization Scale

To see whether the model fits the data, goodness of fit indices was calculated using Amos. Table 2 illustrates the relative chi-square which equals the chi-square index divided by the degrees of freedom $\left(\chi^{2} / \mathrm{df}\right)$, Goodness of Fit Index (CFI), Tucker-Lewis Index (TLI), Comparative Fit Index (CFI), and Root Mean Square Error of Approximation (RMSEA). The criterion for acceptance varies across researchers; in the present study $\chi^{2} / \mathrm{df}$ should be less than 3 and ideally less than 2 (Ullman, 2001), TLI and CFI should be over .90 , and RMS should be less than .08 and ideally less than .05 (Browne \& Cudeck, 1993). 
Table 2.

Goodness of Fit Indices (Contextualization Scale)

\begin{tabular}{lccccc}
\hline Fit index & $\chi^{2} / d f$ & GFI & TLI & CFI & RMSEA \\
\hline Model & 1.66 & .93 & .93 & .99 & .04 \\
\hline
\end{tabular}

According to Table 2, all the goodness of fit indices met the criteria for acceptance. Therefore, the CFA confirmed the factor structure of contextualization scale which was already designed by the authors.

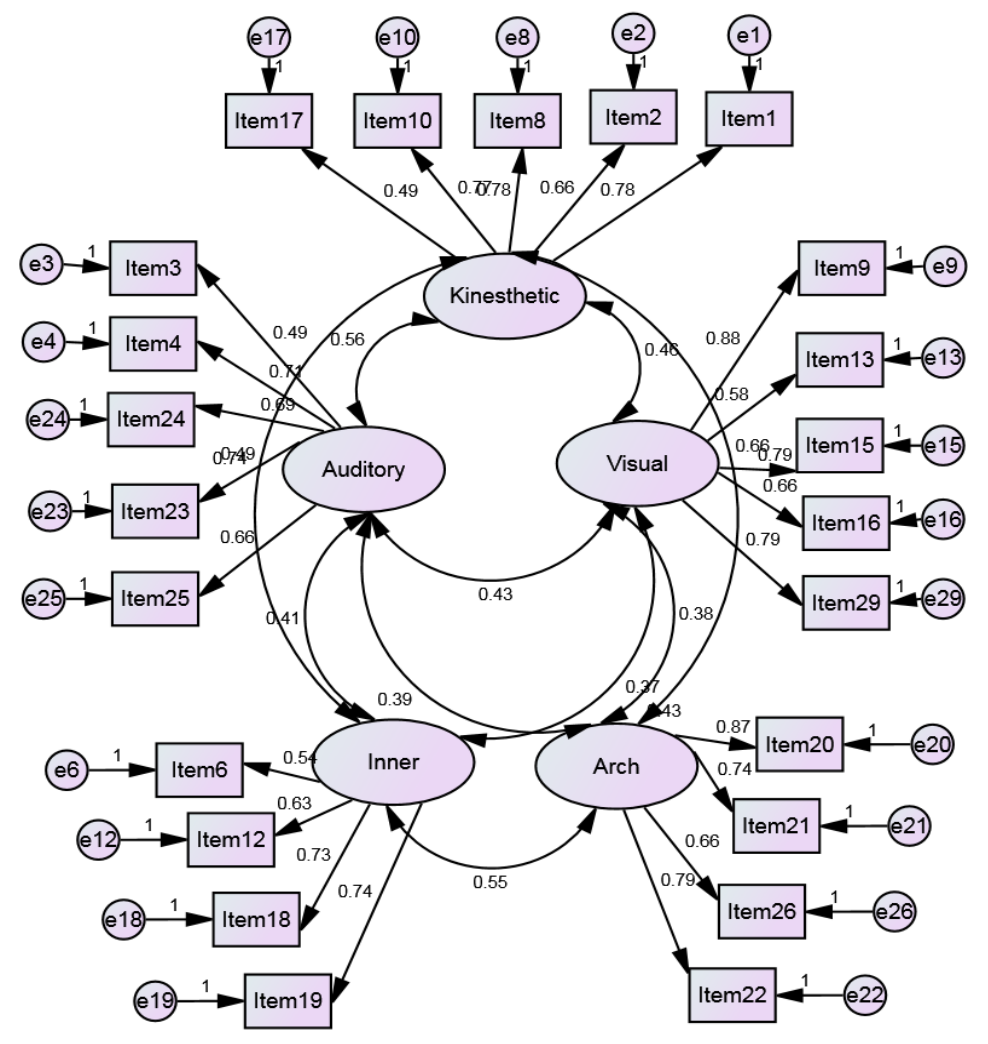

Figure 3. CFA Model for Emotionalization Scale 


\section{Emotionalization Scale}

As demonstrated in Figure 3, a model of emotionalization scale with 5 factors and 23 items was developed through the results of CFA. The model specified 5 dependent variables for Auditory, Visual, and Kinesthetic factors each, and 4 dependent variables for each one of Inner and Arch factors. The model also illustrates the interrelatedness of the latent variables. The figures on the arrows indicate the significance of correlations.

Similar to the contextualization scale, goodness of fit indices was likewise examined for emotionalization scale. Based on the obtained results (Table 3), the model fits the data adequately, hence confirming the structure of the scale.

Table 3

Goodness of Fit Indices (Emotionalization Scale)

\begin{tabular}{lccccc}
\hline Fit index & $\chi^{2} / d f$ & GFI & TLI & CFI & RMSEA \\
\hline Model & 1.52 & .96 & .92 & .91 & .05
\end{tabular}

\section{The Model Proposed by SEM}

SEM, which can be viewed as a combination of factor analysis and regression analysis (MacCallum \& Austin, 2000), was used to link latent variables together and test the theoretical model of the current study.

As can be observed in Figure 4, Involvement (including Arch and Inner factors) and Exvolvement (including Kinesthetic, Visual, and Auditory factors) are introduced as latent variables of emotionalization. Based on the model, the authors observed two separate paths to raising students' level of emotioncy: 1) targeting students' Kinesthetic, Visual, and Arch emotioncies; this is when students are involved from outside (Exvolvement), and 2) targeting students' Arch and Inner emotioncies; this is when students are involved from inside (Involvement).

A brief look at the figure reveals that, all the latent variables significantly predict teacher success to various degrees. Contextualization accounts for $28 \%$ of the variance $\left(\mathrm{R}^{2}=.53\right)$; whereas, emotionalization accounts for $26 \%$ 
of the success variance $\left(\mathrm{R}^{2}=.51\right)$. Therefore, contextualization is a stronger explanatory factor of teacher success than emotionalization $\left(\Delta \mathrm{R}^{2}=.53-.51\right.$ $=.02$ ). Moreover, Involvement and Exvolvement, as the latent factors of emotionalization, explain $14 \%\left(\mathrm{R}^{2}=.38\right)$ and $27 \%\left(\mathrm{R}^{2}=.52\right)$ of the common success variance, respectively. The unique contribution of Exvolvement in predicting teacher success above Involvement was $13 \%\left(\Delta \mathrm{R}^{2}=.52-.38=\right.$ .14). Also, Life and Language, the theoretical models of contextualization, explain $26 \%\left(\mathrm{R}^{2}=.51\right)$ and $17 \%\left(\mathrm{R}^{2}=.42\right)$ of the success variance, respectively. The unique contribution of Language in predicting teacher success above Life was $9 \%\left(\Delta \mathrm{R}^{2}=.51-.42=.09\right)$.

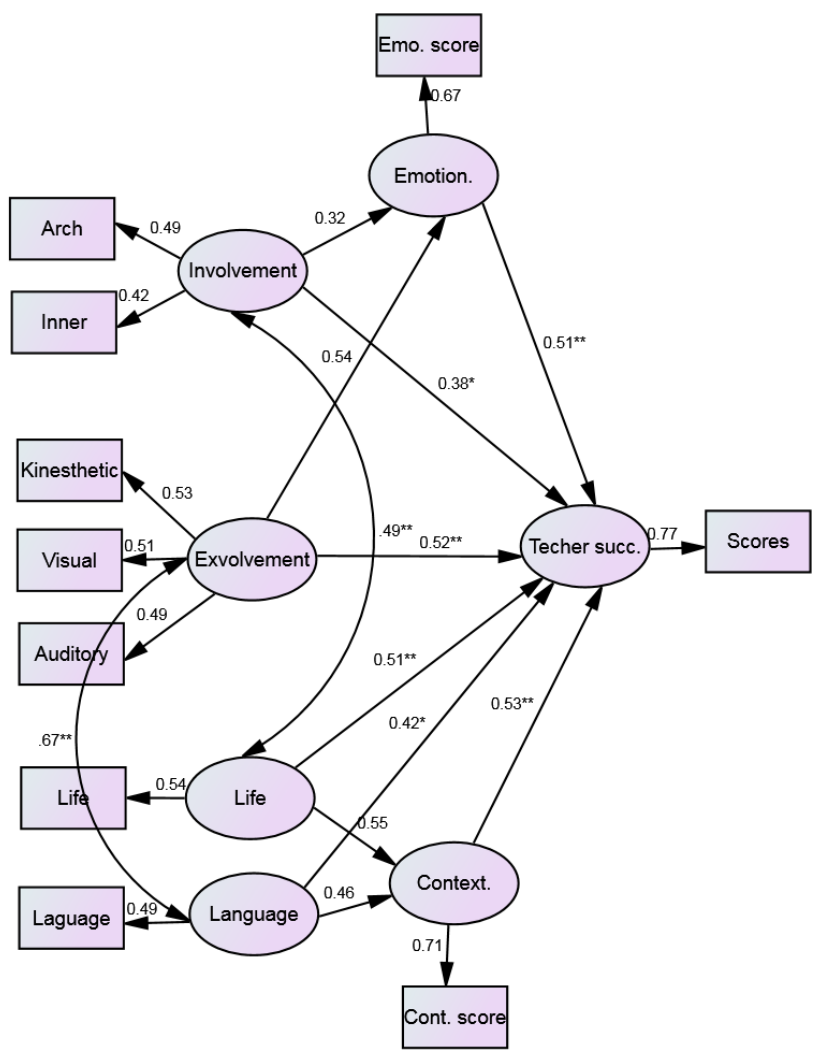

Figure 4. SEM Model of the Relationship among Contextualization, Emotionalization, and Teacher Success 


\section{Pishghadam et al. - Contextualization-Emotionalization Interface}

Besides, the paths in the model connect emotionalization and contextualization with each one reinforcing the other via their variables: relationships are observed between Involvement and Life $(\mathrm{R}=.49)$ and Exvolvement and Language ( $\mathrm{R}=.67)$. Simply put, the two-way relationships between the above latent variables lead to improved teacher success.

To verify the adequacy of the model, goodness of fit indices was examined. Table 4 demonstrates that all the measures are above the cutoff points, hence, a good fit to the data.

Table 4.

Goodness of Fit Indices (SEM Model)

\begin{tabular}{lccccc}
\hline Fit index & $\chi^{2} / d f$ & GFI & TLI & CFI & RMSEA \\
\hline Model & 2.11 & .92 & .91 & .92 & .05 \\
\hline
\end{tabular}

\section{Discussion}

Due to the prominence of the role of teachers in all educational domains, this study attempts to direct attention to their professional success and throw light on further influential features. The primary objective of the study is to construct and validate a pair of scales to measure the extent to which teachers are engaged in the process of contextualization and emotionalization while teaching English. To boot, employing the scales, we aim at elucidating their probable relationships with English language teachers' success.

Regarding the first phase of the study, contextualization and emotionalization scales were developed and afterwards substantiated through CFA. As for the contextualization scale, the model fit the data without removing any items, indicating that all the items appropriately contribute to the model. Based on the results of CFA, it was confirmed that the scale can be best explained by two factors (i.e., Life and Language). Items $1,3,5,7$, and 9 refer to life-pertinent issues and evaluate the extent to which teachers attend to their students' needs and interests, use real life tasks and authentic materials, and stimulate their real life knowledge. Items 2, 4, 
6, 8, and 10 refer to their background knowledge and check teachers' emphasis on authentic materials and situations, non-verbal communication, relatable examples, and teaching aids (e.g., pictures, maps, etc.).

As for the emotionalization scale, CFA results revealed that the scale can be best explained by five factors: Auditory, Visual, Kinesthetic, Inner, and Arch. The first three factors deal with teachers' ability and skill to engage students' senses of hearing, vision, and touch so that to build stronger emotional connections with the new concepts. The last two factors extend students' learning to activities outside the classroom. The 7 items which were consequently irrelevant to the model (i.e., 5, 7, 11, 14, 27, 28, and 30) were removed from the scale ( 1 from Auditory, 1 from Visual, 1 from Kinesthetic, 2 from Inner, and 2 from Arch). Scrutinizing the 7 deleted items, we came up with two possible justifications: first, some items were relatively incompatible with the cultural norms and values of Iran. For instance, teaching through the think aloud protocol (item 5) slightly contradicts the Persian view that verbalization of ones' opinions and emotional experiences may function as a threat to their identity (Pishghadam, 2014). Moreover, as Pishghadam (2014) mentions, not all the individuals are culturally competent to think aloud while doing a job. Second, a number of out-of-class activities, included in the items, required some types of facilities (e.g., field trips or even the Internet!) and considerable amount of time (e.g., infographics), which might not be accessible due to the restrictions set by the language schools of Iran. Thus, a further conclusion drawn from the number of deleted items may be that, relying on their nature, developing Inner and Arch emotioncies call for a large amount of time and sufficient educational facilities.

Regarding the second phase of the study, SEM was employed to conduct an in-depth analysis of the relationships between the independent variables (i.e., contextualization and emotionalization) together with their subconstructs and teacher success. Initial investigation of the model (Figure 4) indicated that, all the latent variables significantly correlate with teacher success. The overall conclusion is that, as teachers contextualize and emotionalize their instructions, they experience more success, and in response learners receive better academic results advocating Afe's (2001) 


\section{Pishghadam et al. - Contextualization-Emotionalization Interface}

statement that teacher success undeniably influences students' academic achievement.

In order to add new perspectives to the concept of teacher success, we reflect upon the estimates obtained from the SEM model. As pointed out earlier, in comparison with emotionalization, contextualization, with a small difference, is a stronger explanatory factor of teacher success. In other words, in this study, cognition stands slightly higher than emotion in terms of its influence on teacher success. This outcome, being in line with Lazarus' (1984) belief that tends toward the primacy of cognition over emotion, challenges Pishghadam, Adamson et al.'s (2013) early assumption that deemotionalization moves a step beyond de-contextualization. Nonetheless, we strongly believe that, the critical role of emotionalized instruction has been underestimated in this context. A possible line of explanation based on which contextualization surpasses emotionalization may be that, we live in an EFL context in which there is no interaction with native speakers, and English is not spoken outside the class. Since Inner emotioncy basically deals with real experiencing of language speaking, it is not surprising to find out contextualization standing above emotionalization. A further probable reason is that, the items of the scale which measure Inner and Arch emotioncies (Involvement) mainly focus on out-of-class activities (e.g., research). Within the Iranian context, these activities are looked at as being rather time-consuming and impractical by the students who are so busy with their school works that hardly find sufficient time for extracurricular classes. In accordance, teachers often prefer to get along with such situations and take advantage of the opportunities available inside the class to develop students' Auditory, Visual, and Kinesthetic emotioncies so far as possible (Exvolvement). To bring the students on board, teachers do their best to make use of frequent types of teaching aids such as audios, pictures, and flashcards (Tomlinson, 2011), aiming to improve their students' Auditory and Visual emotioncies. They likewise target the students' Kinesthetic emotioncy, by lingering on Dewey's (1916) pragmatic view of learning-bydoing and practical development of life skills, through which they engage the students in well-designed hands-on activities. This prolonged struggle characterizes more successful learners and teachers. As the model further depicted, Exvolvement predicts teacher success better than Involvement. 
This is in large part due to the fact that, Exvolvement-oriented activities, for the sake of their practicality, are practiced at the expense of Involvementoriented activities in ELT classes. Based on the tenants of concept learning, understanding takes place when one experiences the related examples (Wisniewski \& Medin, 1994). In this manner, when learners are rarely exposed to involvement-provoking instructions, they may have no clear understanding of its examples to ultimately give proper weight to teacher success. However, the moderately big $\mathrm{R}^{2}$ estimate of emotionalization reveals that, if teachers are able to put involvement-oriented activities into practice, students' emotional reactions will be far from indisputable. An interesting point is that, between Life and Language, as the sub-constructs of contextualization scale, Life's degree of association with teacher success surpasses that of Language. In correspondence with Dewey's (1916) integration of life into teaching curriculum, this notion indicates that, although English teachers need to contextualize their instructions, this should be generally done through the lens of life-responsive teaching (Pishghadam \& Zabihi, 2012). This line of reasoning renders the idea of educational language teacher proposed by Pishghadam and Zabihi (2012) which has its roots in the theory of Applied ELT brought forth by Pishghadam (2011). They, indeed, believe that, English teachers are expected to be experts in both language and life matters.

Over and above, what merits additional consideration is that, contextualization and emotionalization have hooked up through the relationship between their sub-constructs. While Involvement significantly correlates with Life, Exvolvement correlates with Language. It is somewhat logical to infer that, in order for learners to experience Involvement, teachers are required to help them build an associative bridge between life and classroom and expand their learning to the outside world. Highlighting the significance of post-classroom experiences, Pegrum (2000) considers them as an extension of every ELT classroom. Yet, in order to trigger students' background knowledge, various techniques and teaching aids are drawn upon by teachers, which in turn influence the Exvolvement aspect of emotioncy. After all, studying the interwoven network of relationships suggested by the SEM model, we may deduce that contextualization coupled with emotionalization may give rise to teacher success. In other words, the 
two concepts of contextualization and emotionalization are not mutually exclusive, yet can be practiced together with varying degrees of emphasis. This finding is quite close to the idea of concept learning, arguing that learners learn best when their prior knowledge and experience are both involved (Wisniewski \& Medin, 1994). Therefore, juxtaposition of contextualization (prior knowledge) and emotionalization (experience) is expected to yield better results on the part of both learners and teachers. This, of course, supports the view according to which, the seemingly contradictory notions of cognition and emotion are not only interdependent but also conceptually linked together (e.g., Dewey, 1894; Parrott \& Sabini, 1989). We believe that neither views on cognition/emotion primacy may hold true at all times, and teachers' overall success depends, to a large extent, on the context they are in.

In brief, from the viewpoint of this study, a successful teacher is the one who strikes a balance between language and life pursuing the emotions learners bring to the class from their L1. Contextualization as an alreadyknown concept has more or less been applied in English classes for long; yet, emotionalization, being very much in its infancy, needs to be accentuated as a supplementary concept. Like Applied ELT, emotionalization is believed to be an exclusive feature of English language classes which still requires much labor to win its own place in the sphere of language education. As it is proposed, spicing the classes with some activities provoking L1-related emotions, can jack up teacher success. Considering the irrefutable bond between teacher success and students' achievement, it is assumed that, as the students gradually proceed along the emotioncy level metric and leave Exvolvement toward Involvement, their level of autonomy rises from dependent to independent learners. Nonetheless, further studies need to be conducted to investigate such issue empirically.

\section{References}

Afe, J. O. (2001). Reflections on becoming a teacher and the challenges of teacher education. Inaugural Lecture Series 64. Benin City: University of Benin, Nigeria. 
Ausubel, D. (1968). Educational psychology: A cognitive view. New York: Holt, Rienhart and Winston.

Baker, M. (2006). Contextualization in translator- and interpreter-mediated events. Journal of Pragmatics, 38(3), 321-337. doi: 10.1016/j.pragma.2005.04.010

Bartlett, F. C. (1932). Remembering: A study in experimental and social psychology. Cambridge: Cambridge University Press.

Bax, S. (2003). The end of CLT: A context approach to language teaching. ELT Journal, 57(3), 278-87. doi: 10.1016/0346-251X(93)90058-O

Beck, W. R. (1967). Pupils' perceptions of teacher merit: A factor analysis of five postulated dimensions. The Journal of Educational Research, 61(3), 127-128. doi: 10.1080/00220671.1967.10883612

Bhardwaj, A. (2009). Role of personality factors for teaching effectiveness. Pacific Business Review: A Quarterly Journal of Management, 2, 7580.

Brophy, J. (1988). Educating teachers about managing classrooms and students. Teaching and Teacher Education, 4(1), 1-18.

Brown, H. D. (2000). Principles of language learning and teaching. NY: Longman.

Browne, M. W., \& Cudeck, R. (1993). Alternative ways of assessing model fit. In K. A. Bollen \& J. S. Long (Eds.), Testing structural equation models (pp. 136-162). CA: Sage.

Cameron, L. (2001). Teaching languages to young learners. Cambridge: Cambridge University Press. doi: CBO9780511733109

Campbell, J., Kyriakides, L., Muijs, D., \& Robinson, W. (2004). Assessing teacher effectiveness. NY: Routledge Falmer. doi: 10.4324/9780203403709

Celce-Murcia, M. (2002), Why it makes sense to teach grammar in context and through discourse. In E. Hinkel, \& S. Fotos (Eds.), New perspectives on grammar teaching in second language classrooms (pp. 119-134). Mahwa, NJ: Lawrence Erlbaum.

Cordova, D. I., \& Lepper, M. R. (1996). Intrinsic motivation and the process of learning: Beneficial effects of contextualization, personalization, and choice. Journal of Educational Psychology, 88(4), 715-730. 
122 Pishghadam et al. - Contextualization-Emotionalization Interface

Dewey, J. (1916). Democracy and education: An introduction to the philosophy of education. New York: Macmillan.

Dewey J. (1894). The ego as cause. Philosophical Review, 3, 337-341. doi: $10.2307 / 2175977$

Dodge, A. F. (1943). What are the personality traits of the successful teacher? Journal of Applied Psychology, 27, 325-337. doi: 10.1037/h0062404

Elizabeth, C. L., May, C. M., \& Chee, P. K. (2007). Building a model to define the concept of teacher success in Hong Kong. Teaching and Teacher Education, 24, 623-634. doi: 10.1016/j.tate.2007.09.007

Ellett, C. D., \& Teddlie, C. (2003). Teacher evaluation, teacher effectiveness and school effectiveness: Perspectives from the USA. Journal of Professional Evaluation in Education, 17(1), 101-128. doi: 10.1023/A:1025083214622

Fox, J. P. (2010). Bayesian item response modeling: Theory and applications. New York: Springer. doi: 10.1007/978-1-4419-0742-4

Greenspan, S. I. (1992). Infancy and early childhood: The practice of clinical assessment and intervention with emotional and developmental challenges. Madison, CT: International Universities Press.

Greenspan, S. I. (1997). The growth of the mind and the endangered origins of intelligence. Reading. MA: Addison Wesley Longman.

Greenspan, S. I. (2001). The affect diathesis hypothesis: The role of emotions in the core deficits in autism and in the development of intelligence and social skills. Journal of Developmental and Learning Disorders, 5, 1-46.

Johnson, S. M., \& Birkeland, S. E. (2003). Pursuing a "sense of success": New teachers explain their career decisions. American Educational Research Journal, 40(3), 581-617. doi: 10.3102/00028312040003581

Korthagen, F. A. J. (2004). In search of the essence of a good teacher: Towards a more holistic approach in teacher education. Teaching and Teacher Education, 20, 77-97. doi: 10.1016/j.tate.2003.10.002

Lazarus, R. S. (1984). On the primacy of cognition. American Psychologist, 39, 124-129. doi: 10.1037/0003-066X.39.2.124 
Leventhal, H., \& Scherer, K. (1987). The relationship of emotion to cognition: A functional approach to a semantic controversy. Cognition \& Emotion, 1(1), 3-28.

MacCallum, R. C., \& Austin, J. T. (2000). Applications of structural equation modeling in psychological research. Annual Review of Psychology, 51, 201-226. doi: 10.1146/annurev.psych.51.1.201

Mangiante, E. M. S. (2011). Teachers matter: Measures of teacher effectiveness in low-income minority schools. Educational Assessment Evaluation Accreditation, 23(1), 41-63. doi: 10.1007/s11092-010-9107-x

Medley, D. M., \& Mitzel, H.E. (1955). Some behavioral correlates of teacher effectiveness. Journal of Educational Psychology, 46(6), 330344.

Moafian, F., \& Pishghadam, R. (2008). Construct validation of a questionnaire on characteristics of successful English language teachers. Pazhuhesh-e Zabanheye Khareji Journal (University of Tehran), 54, 127-142.

Monshi Toussi, M. T., Boori, A. A., \& Chanizadeh, A. (2011). The role of EFL teachers' self-regulation in effective teaching. World Journal of Education, 1(2), 39-48. doi: 10.5430/wje.v1n2p39

Nunan, D. (1999). Second language teaching and learning. Boston: Heinle \& Heinle.

Palardy, G. J., \& Rumberger, R. W. (2008). Teacher effectiveness in first grade: The importance of background qualifications, attitudes, instructional practices for student learning. Educational Evaluation and Policy Analysis, 30, 111-140. doi: 10.3102/0162373708317680

Parrott, G., \& Sabini J. (1989). On the emotional qualities of certain types of cognition: A reply to arguments for the independence of cognition and affect. Cognitive Therapy and Research, 13, 49-65. doi: 10.1007/BF01178489

Pegrum, M.A. (2000). The outside world as an extension of the EFL/ESL classroom. The Internet TESL Journal, 6(8). Retreived from http://iteslj.org/Lessons/Pegrum-OutsideWorld.html 
Piaget, J. (1959). The language and thought of the child. Paris: Psychology Press.

Pishghadam, R. (2011). Introducing applied ELT as a new paradigm. Iranian EFL Journal, 7(2), 9-20.

Pishghadam, R. (2014). Asibshenasi raveshhaye jamavarie dade dar motale'ate zabani: Gami be sooye boomisazi ravesh tahghigh dar Iran [Investigating data collection methods in language studies: A step towards localizing research methodology in Iran]. Language Related Research, 2(18), 55-70.

Pishghadam, R. (2015, October). Emotioncy in language education: From exvolvement to involvement. Paper presented at the $2^{\text {nd }}$ Conference on Interdisciplinary Approaches to Language Teaching, Literature, and Translation Studies, Mashhad, Iran.

Pishghadam, R., Adamson, B., \& Shayesteh, S. (2013). Emotion-based language instruction (EBLI) as a new perspective in bilingual education. Multilingual Education, 3(9), 1-16. doi: 10.1186/21915059-3-9

Pishghadam, R., Jajarmi, H., \& Shayesteh, S. (in press). Conceptualizing sensory relativism in light of emotioncy: A movement beyond linguistic relativism. International Journal of Society, Culture \& Language.

Pishghadam, R., \& Shams, M. (2012). Hybrid modeling of intelligence and linguistic factors as predictors of L2 writing quality: A SEM approach. Language Testing in Asia, 2(3), 53-76. doi: 10.1186/22290443-2-3-53

Pishghadam, R., Shayesteh, S., \& Shapoori, M. (2011). Validation of an NLP scale and its relationship with teacher success in high schools. Journal of Language Teaching and Research, 2(4), 909-917. doi: 10.4304/jltr.2.4.909-917

Pishghadam, R., Tabatabaeyan, M. S., \& Navari, S. (2013). A critical and practical analysis of first language acquisition theories: The origin and development. Iran, Mashhad: Ferdowsi University of Mashhad Publications.

Pishghadam, R., \& Zabihi, R. (2012). Life syllabus: A new research agenda in English language teaching. Perspectives, 19(1), 23-27. 
Porter, A., \& Brophy, J. (1988). Synthesis of research on good teaching: Insights from the work of the institute of research on teaching. Educational Leadership, 45(8), 74-85.

Richards, J. C., \& Rodgers, T. S. (2001). Approaches and methods in language teaching $\left(2^{\text {nd }}\right.$ ed.). Cambridge, New York: Cambridge University Press. doi: 10.1017/CBO9780511667305

Shrum, J., \& Glisan, E. (1994). Teacher's handbook: Contextualized language instruction. USA: Heinle \& Heinle.

Son, J. Y., \& Goldstone, R. L. (2009). Contextualization in perspective. Cognition and Instruction, 27, 1-39. doi: 10.1080/07370000802584539

Stone, J. R., III, Alfeld, C., Pearson, D., Lewis, M. V., \& Jensen, S. (2006). Building academic skills in context: Testing the value of enhanced math learning in CTE (Final study). St. Paul, MN: National Research Center for Career and Technical Education.

Thornbury, S. (1999). How to teach grammar. Essex: Pearson Education.

Tomlinson, B. (2011). Materials development in language teaching $\left(2^{\text {nd }} \mathrm{ed}.\right)$. Cambridge: Cambridge University Press.

Uchefuna, M. C. (2001). A study of clinical supervision and teachers effectiveness in Umuahia and Abia educational zones of Abia State (Unpublished M.Ed. dissertation). University of Port Harcourt, Harcourt, Nigeria.

Ullman, J. B. (2001). Structural equation modeling. In B. G. Tabachnick \& L. S. Fidell (Eds.), Using multivariate statistics ( $4^{\text {th }}$ ed., pp. 653-771). Needham Heights, MA: Allyn \& Bacon.

Vygotsky, L. S. (1978). Mind in society: The development of higher psychological processes. Cambridge, MA: Harvard University Press.

Walz, J. (1989). Context and contextualized language practice in foreign language teaching. Modern Language Journal, 73(2), 160-168. doi: 10.1111/j.1540-4781.1989.tb02538.x

Widdowson, H. G. (2004). Text, context, and pretext: Critical issues in discourse analysis. Oxford: Blackwell. doi: 10.1002/9780470758427

Wisniewski, E. J., \& Medin, D. L. (1994). On the interaction of theory and data in concept learning. Cognitive Science, 18, 221-281. doi: $10.1207 / \mathrm{s} 15516709 \operatorname{cog} 1802 \_2$ 


\section{Appendices}

\section{Appendix 1}

Sample Items of the Contextualization Scale

$\underline{\text { Life }}$

My teacher assigns and personalizes homework based on our interests, needs and goals.

My teacher makes us work on tasks which are directly related to our life goals.

\section{Background}

My teacher asks us to pay attention to the physical settings such as pictures, maps, objects etc.

My teacher gives us similar examples of relatable background to the new concepts.

\section{Appendix 2}

Sample Items of the Emotionalization Scale

\section{$\underline{\text { Audio }}$}

My teacher encourages us to watch TV and listen to the radio in English.

Visual

My teacher uses pantomime to help us understand new words.

Kinesthetic

My teacher asks us to design infographics (graphic information) for certain concepts.

\section{$\underline{\text { Inner }}$}

My teacher takes us to online field trips such as online tours to museums, planetariums etc. 
Arch

My teacher wants us to do some research on certain new concepts and present it in the class.

Reza Pishghadam is a professor of language education and a courtesy professor of educational psychology at Ferdowsi University of Mashhad, Iran

Shaghayegh Shayesteh is a $\mathrm{PhD}$ candidate studying Teaching English as a Foreign Language at Ferdowsi University of Mashhad, Iran

Simindokht Rahmani is an MA holder in Teaching English as a Foreign Language at Ferdowsi University of Mashhad, Iran

Contact Address: English Department, Ferdowsi University of Mashhad, Iran. Email: pishghadam@um.ac.ir 